\title{
Investigations on Some Biologically Active Divalent Transition Metal Complexes with Ditellurium Tetraazamacrocycles
}

\author{
SUMIT KUMARI and SAPANA GARG* \\ Department of Chemistry, Maharshi Dayanand University, Rohtak-124001, India \\ sapanagarg1511@gmail.com
}

Received 16 July 2018 / Accepted 5 August 2018

\begin{abstract}
Some 10-membered ditellurium tetraazamacrocyclic complexes of $\mathrm{Ni}(\mathrm{II}), \mathrm{Pd}(\mathrm{II})$ and $\mathrm{Pt}(\mathrm{II})$ were synthesized by template condensation of diaryltellurium(IV) dichlorides, $(\operatorname{aryl}=p$ methoxyphenyl, 3-methyl-4-hydroxyphenyl and $p$-hydroxyphenyl) with 1,2-diaminopropane and divalent metal chlorides in dry methanol. Characterization of these newly synthesized complexes was carried out by elemental analyses, magnetic susceptibility measurement and Infrared, proton nuclear magnetic resonance and electronic absorption spectroscopy. On the basis of these studies, a square planar geometry has been assigned for $\mathrm{Pd}(\mathrm{II})$ and $\mathrm{Pt}(\mathrm{II})$ complexes and a distorted octahedral geometry for the $\mathrm{Ni}$ (II) complexes. The antibacterial and antifungal activities of these complexes, have also been screened in vitro against some pathogenic fungal and bacterial strains to assess their growth inhibiting potential. The MIC shown by these complexes were compared with the MIC shown by standard antifungal (fluconazole) and antibacterial (cefadroxil) drugs.
\end{abstract}

Keywords: $p$-Hydroxyphenyl, Diaryltellurium(IV), Template condensation, Antibacterial activity, 1, 2-Diaminopropane

\section{Introduction}

The area of coordination chemistry of polyazamacrocycles has been studied extensively ${ }^{1-3}$. Template synthesis lies at the centre of macrocyclic chemistry ${ }^{4}$. Therefore, template reactions have been used widely to synthesize the macrocyclic complexes, containing metals as templates 5 . Recently, the polyazamacrocycles have engendered much research due to their vast applications as antitumour ${ }^{6-8}$, antibacterial ${ }^{9-11}$, antifertile ${ }^{12}$, anti-infilamatory ${ }^{13}$, anticonvulsant ${ }^{14}$ and antifungal agents along with other biological properties ${ }^{15-17}$. Platinum and palladium complexes are also widely used in anticancer therapy ${ }^{18-21}$. Metal complexes of macrocycles are also significant due to their use as NMR shift reagents ${ }^{22}$, catalysts in oxidation and epoxidation processes ${ }^{23,24}$ as well as dyes and pigments ${ }^{25}$.

Organotellurium ligands containing hard and soft donors like nitrogen, oxygen and tellurium results into an interesting coordination chemistry due to the competitive coordination 
behaviour between the hard and soft donors towards the metal ${ }^{26,27}$. Organotellurium compounds have been utilized as organic superconductors ${ }^{28}$, semiconductors ${ }^{29}$ and photo imaging agents. Development of tellurium containing macrocycles and template synthetic routes for the transition metal complexes of tellurium containing tetraazamacrocycles have also been reported ${ }^{30-32}$.

Following these facts, synthesis and characterization of 10-membered ditellurium tetraazamacrocyclic complexes of $\mathrm{Ni}(\mathrm{II}), \mathrm{Pd}(\mathrm{II})$ and $\mathrm{Pt}(\mathrm{II})$ are discussed in this paper. The synthesized metal complexes were characterized by elemental analyses, magnetic susceptibility measurements, infra-red, nuclear magnetic resonance and electronic absorption spectroscopy. These complexes have also been tested in vitro for their antibacterial and antifungal activity.

\section{Experimental}

The $\mathrm{C}, \mathrm{H}$ and $\mathrm{N}$ analyses were obtained from SAIF, Panjab University, Chandigarh on a Microprocessor based thermo scientific (FLASH 2000) CHNS-O organic elemental analyser (Table 1). Tellurium and chlorine contents were determined volumetrically ${ }^{33(a), 33(b)}$ while palladium and platinum gravimetrically ${ }^{33(\mathrm{c}), 33(\mathrm{~d})}$. Nickel was estimated on atomic absorption spectrophotometer (ECIL Model No.4129). Electronic spectra were recorded in barium sulphate at $25 \pm 2{ }^{\circ} \mathrm{C}$ on a UV-VIS-NIR spectrophotometer; model UV-3600 Plus (SHIMADZU). IR (4000-400 $\mathrm{cm}^{-1}$ using $\mathrm{KBr}$ ) and far IR (40-500 $\mathrm{cm}^{-1}$ using polyethylene) spectra were recorded on F.T. infra-red spectrometer model Nicolet IS50 (Thermo Scientific).

Table 1. Analytical data, physical properties and molar conductance for metal complexes

\begin{tabular}{|c|c|c|c|c|c|c|c|c|c|c|}
\hline \multirow[b]{2}{*}{ Complex } & \multirow{2}{*}{$\begin{array}{l}\text { Empirical formula } \\
\text { (Formula weight) }\end{array}$} & \multirow[b]{2}{*}{ olor } & \multirow[b]{2}{*}{ 1.P. ${ }^{\circ} \mathrm{C}$} & \multirow{2}{*}{$\begin{array}{l}\text { Yield } \\
\%\end{array}$} & \multicolumn{6}{|c|}{ Analysis found (calculated), $\%$} \\
\hline & & & & & $\mathrm{C}$ & $\mathrm{H}$ & $\mathrm{N}$ & $\mathrm{Cl}$ & $\mathrm{Te}$ & M \\
\hline$\left[\mathrm{NiL}^{1} \mathrm{Cl}_{2}\right]$ & $\begin{array}{c}\mathrm{C}_{30} \mathrm{H}_{36} \mathrm{Cl}_{2} \mathrm{~N}_{4} \mathrm{O}_{4} \mathrm{Te}_{2} \mathrm{Ni} \\
(901.43)\end{array}$ & own & $140-$ & 72 & $\begin{array}{c}39.61 \\
(39.97)\end{array}$ & $\begin{array}{c}4.66 \\
(4.03)\end{array}$ & $\begin{array}{c}6.00 \\
(6.22)\end{array}$ & $\begin{array}{l}7.78 \\
(7.87)\end{array}$ & $\begin{array}{c}28.20 \\
(28.31)\end{array}$ & $\begin{array}{c}6.25 \\
(6.51)\end{array}$ \\
\hline$\left.l_{2}\right]$ & $\begin{array}{c}\mathrm{C}_{34} \mathrm{H}_{44} \mathrm{Cl}_{2} \mathrm{~N}_{4} \mathrm{O}_{4} \mathrm{Te}_{2} \mathrm{Ni} \\
(957.54)\end{array}$ & $\begin{array}{l}\text { Light } \\
\text { green }\end{array}$ & 2 & 68 & $\begin{array}{c}42.34 \\
(42.65)\end{array}$ & $\begin{array}{c}4.74 \\
(4.63)\end{array}$ & $\begin{array}{c}5.49 \\
(5.85)\end{array}$ & $\begin{array}{c}7.19 \\
(7.41)\end{array}$ & $\begin{array}{c}26.26 \\
(26.65)\end{array}$ & $\begin{array}{c}5.98 \\
(6.13)\end{array}$ \\
\hline$\left[\mathrm{NiL}^{3} \mathrm{Cl}_{2}\right]$ & $\begin{array}{c}\mathrm{C}_{34} \mathrm{H}_{44} \mathrm{Cl}_{2} \mathrm{~N}_{4} \mathrm{O}_{4} \mathrm{Te}_{2} \mathrm{Ni} \\
(957.54)\end{array}$ & $\begin{array}{l}\text { Light } \\
\text { Green }\end{array}$ & $128-130$ & 67 & $\begin{array}{c}42.34 \\
(42.65)\end{array}$ & $\begin{array}{c}4.34 \\
(4.63)\end{array}$ & $\begin{array}{c}5.59 \\
(5.85)\end{array}$ & $\begin{array}{c}7.31 \\
(7.41)\end{array}$ & $\begin{array}{c}26.26 \\
(26.65)\end{array}$ & $\begin{array}{c}5.90 \\
(6.13)\end{array}$ \\
\hline$[\mathrm{PdI}$ & $\begin{array}{c}\mathrm{C}_{30} \mathrm{H}_{36} \mathrm{Cl}_{2} \mathrm{~N}_{4} \mathrm{O}_{4} \mathrm{Te}_{2} \mathrm{Pd} \\
(949.16)\end{array}$ & $\begin{array}{l}\text { Light } \\
\text { yellow }\end{array}$ & 22 & 66 & $\begin{array}{c}37.59 \\
(37.96)\end{array}$ & $\begin{array}{c}3.63 \\
(3.82)\end{array}$ & $\begin{array}{c}5.76 \\
(5.90)\end{array}$ & $\begin{array}{c}7.29 \\
(7.47)\end{array}$ & $\begin{array}{c}26.99 \\
(26.89)\end{array}$ & $\begin{array}{l}11.01 \\
(11.21)\end{array}$ \\
\hline$\left[\mathrm{PdL}^{2}\right] \mathrm{Cl}_{2}$ & $\begin{array}{c}\mathrm{C}_{34} \mathrm{H}_{44} \mathrm{Cl}_{2} \mathrm{~N}_{4} \mathrm{O}_{4} \mathrm{Te}_{2} \mathrm{Pd} \\
(1020.30)\end{array}$ & rown & $155-157$ & 61 & $\begin{array}{c}40.04 \\
(40.38)\end{array}$ & $\begin{array}{c}4.55 \\
(4.39)\end{array}$ & $\begin{array}{c}5.30 \\
(5.54)\end{array}$ & $\begin{array}{c}6.89 \\
(7.01)\end{array}$ & & $\begin{array}{c}10.92 \\
(11.12)\end{array}$ \\
\hline $\mathrm{Cl}_{2}$ & $\begin{array}{c}\mathrm{C}_{34} \mathrm{H}_{44} \mathrm{Cl}_{2} \mathrm{~N}_{4} \mathrm{O}_{4} \mathrm{Te}_{2} \mathrm{Pd} \\
(1020.30)\end{array}$ & $\begin{array}{l}\text { Light } \\
\text { Brown }\end{array}$ & & 69 & $\begin{array}{c}40.88 \\
(41.20)\end{array}$ & $\begin{array}{c}3.49 \\
(4.64)\end{array}$ & $\begin{array}{c}5.21 \\
(5.49)\end{array}$ & $\begin{array}{c}6.81 \\
(6.95)\end{array}$ & $\begin{array}{c}25.28 \\
(25.01)\end{array}$ & $\begin{array}{c}10.21 \\
(10.43)\end{array}$ \\
\hline$\left[\mathrm{PtL}^{1}\right] \mathrm{Cl}_{2}$ & $\begin{array}{c}\mathrm{C}_{30} \mathrm{H}_{36} \mathrm{Cl}_{2} \mathrm{~N}_{4} \mathrm{O}_{4} \mathrm{Te}_{2} \mathrm{Pt} \\
(1037.82)\end{array}$ & ach & $132-134$ & 10 & $\begin{array}{c}34.34 \\
(34.72)\end{array}$ & $\begin{array}{c}3.66 \\
(3.50)\end{array}$ & $\begin{array}{c}5.21 \\
(5.40)\end{array}$ & $\begin{array}{c}6.42 \\
(6.83)\end{array}$ & $\begin{array}{c}24.25 \\
(24.59)\end{array}$ & $\begin{array}{c}18.65 \\
(18.80)\end{array}$ \\
\hline & $\begin{array}{c}\mathrm{C}_{34} \mathrm{H}_{44} \mathrm{Cl}_{2} \mathrm{~N}_{4} \mathrm{O}_{4} \mathrm{Te}_{2} \mathrm{Pt} \\
(1108.96)\end{array}$ & n & 183 & 65 & $\begin{array}{c}37.45 \\
(37.91)\end{array}$ & $\begin{array}{c}4.06 \\
(4.27)\end{array}$ & $\begin{array}{c}4.81 \\
(5.05)\end{array}$ & $\begin{array}{c}6.29 \\
(6.39)\end{array}$ & $\begin{array}{c}23.15 \\
(23.01)\end{array}$ & $\begin{array}{c}17.29 \\
(17.59)\end{array}$ \\
\hline$\left[\mathrm{PtL}^{3}\right] \mathrm{Cl}_{2}$ & $\begin{array}{c}\mathrm{C}_{34} \mathrm{H}_{44} \mathrm{Cl}_{2} \mathrm{~N}_{4} \mathrm{O}_{4} \mathrm{Te}_{2} \mathrm{Pt} \\
(1108.96)\end{array}$ & $\begin{array}{l}\text { Light } \\
\text { yellow }\end{array}$ & $113-115$ & 67 & $\begin{array}{c}37.45 \\
(37.91)\end{array}$ & $\begin{array}{c}4.06 \\
(4.27) \\
\end{array}$ & $\begin{array}{c}4.81 \\
(5.05) \\
\end{array}$ & $\begin{array}{r}6.19 \\
(6.39) \\
\end{array}$ & $\begin{array}{c}23.20 \\
(23.01) \\
\end{array}$ & $\begin{array}{c}17.39 \\
(17.59) \\
\end{array}$ \\
\hline
\end{tabular}

*decomposition temperature

Nuclear magnetic resonance spectra were recorded in DMSO- $\mathrm{d}_{6}$ at SAIF, Panjab University and Chandigarh using TMS as an internal standard on BRUKER AVANCE II 
Chem Sci Trans., 2019, 8(1), 48-59

400 NMR spectrometer. Magnetic mass susceptibility data were obtained from NPL, New Delhi on a Gouy's balance (model Johnson Matthey Alfa products) using glycerin as a calibrant. Purity of the complexes was controlled by thin layer chromatography. Silica gel plates $0.25 \mathrm{~mm}, 60 \mathrm{GF}_{254}$, pre coated sheets, obtained from Merck, were used for TLC and spots were visualized by iodine vapour as visualizing agents. The chemicals used for the synthesis were purchased from Fluka, Sigma-Aldrich, Loba Chemie and spectrochem. The Solvents, anisole, phenol and $o$-cresol were purified by standard methods ${ }^{34}$ prior to use. Air and moisture sensitive reactions were carried out under dry $\mathrm{N}_{2}$ atmosphere. Melting points were determined in open capillary tube and are uncorrected.

\section{Preparation of diaryltellurium(IV) dichlorides}

Bis(p-hydroxyphenyl)tellurium(IV)dichloride ${ }^{35}$, bis(3-methyl-4-hydroxyphenyl)tellurium(IV) dichloride $^{36}$ and bis( $p$-methoxyphenyl)tellurium(IV)dichloride ${ }^{37}$ were prepared by direct reactions of tellurium tetrachloride with phenol, $o$-cresol and anisole respectively, as reported in the literature.

\section{Preparation of metal complexes with 10-membered ditellurium tetraazamacrocycles}

The complexes were synthesized by the template condensation reactions of diaryltellurium(IV)dichlorides and 1, 2-diaminopropane with divalent metal chlorides in 2: 2: 1 molar ratios. Genaral procedure is given below:

A saturated and hot solution of $5.0 \mathrm{mmol}$ of diaryltellurium(IV)dichloride $(1.925 \mathrm{~g}$, $2.065 \mathrm{~g}$ and $2.065 \mathrm{~g}$ for bis( $p$-hydroxyphenyl), bis( $p$-methoxyphenyl) and bis(3-methyl-4hydroxyphenyl)tellurium dichloride, respectively) in methanol was added dropwise to a stirred methanolic solution $(\sim 5 \mathrm{~mL})$ of 1, 2-diaminopropane $(5.0 \mathrm{mmol}, 0.370 \mathrm{~g})$ taken in a round bottom flask. An immediate change in colour was observed. The contents were refluxed for 3-4 h followed by the addition of $2.5 \mathrm{mmol}$ of saturated methanolic solution of divalent metal chlorides $\left(0.595 \mathrm{~g}, 0.442 \mathrm{~g}\right.$ and $0.665 \mathrm{~g}$ for $\mathrm{NiCl}_{2} \cdot 6 \mathrm{H}_{2} \mathrm{O}, \mathrm{PdCl}_{2}$ and $\mathrm{PtCl}_{2}$ respectively). This resulted in a distinct change in colour. The mixture was then again refluxed for 7-8 $\mathrm{h}$ and cooled to room temperature. The filtrate was concentrated and kept in refrigerator to obtain the crystalline product. This was filtered, washed with petroleum-ether and dried in a vacuum desiccator over $\mathrm{P}_{4} \mathrm{O}_{10}$.

\section{In vitro antimicrobial activity}

Antibacterial and antifungal activity of the synthesized complexes were carried out using tube dilution method ${ }^{38}$ against five test pathogenic bacterial strains viz., Staphylococcus aureus (MTCC 2901), Bacillus subtilis (MTCC 2063) Bacillus cereus (MTCC 7350), Escherichia coli (MTCC 1652) and Salmonella typhi (ATCC 15499) and three pathogenic fungal strains viz., Candida albicans(MTCC 227), Aspergillus niger (MTCC 8189) and Aspergillus fumigatus (ITCC 4517). Cefadroxil and fluconazole were taken as standard antibacterial and antifungal drugs respectively. All the complexes were dissolved in dimethylsulfoxide (DMSO) to give a conc. of $100 \mu \mathrm{g} / \mathrm{mL}$. The test and standard compound were both serially diluted in Double strength nutrient broth for bacteria and sabouraud dextrose broth for fungi ${ }^{39}$ to get the desired conc. range $(50-1.56 \mu \mathrm{g} / \mathrm{mL})$. The inoculum size was approximately $10^{6}$ colony forming units (CFU) $\mathrm{mL}^{-1}$. The cultures were incubated at $37 \pm 2{ }^{\circ} \mathrm{C}$ for $24 \mathrm{~h}$ (bacteria) and at $25 \pm 1{ }^{\circ} \mathrm{C}$ for $7 \mathrm{~d}$ (A. niger), $37 \pm 2{ }^{\circ} \mathrm{C}$ for $48 \mathrm{~h}($ C. albicans $), 35 \pm 2{ }^{\circ} \mathrm{C}$ for $72 \mathrm{~h}$ (A. fumigatus) and after incubation tubes were macroscopically examined for turbidity. Results were stated in terms of minimum inhibitory concentration (MIC). MIC is the lowest concentration of an antimicrobial agent that prevents the viable growth after required incubation. 


\section{Results and Discussion}

\section{Synthesis}

Phenol ${ }^{35} / o$-cresol ${ }^{36} /$ anisole $^{37}(\mathrm{R}-\mathrm{H})$ when heated with $\mathrm{TeCl}_{4}$ an electrophilic substitution reaction appears to undergo where $\mathrm{TeCl}_{3}{ }^{+}$unit attacks a position para to the hydroxyl/methoxy group in the aromatic rings (equation 1). These aryltellurium(IV)trichlorides formed in step 1 further react with phenol/o-cresol/anisole to give diaryltelluriumdichlorides as per equation 2 .

$$
\begin{array}{r}
\mathrm{R}-\mathrm{H}+\mathrm{TeCl}_{4} \rightarrow \mathrm{RTeCl}_{3}+\mathrm{HCl} \\
\mathrm{RTeCl}_{3}+\mathrm{R}-\mathrm{H} \rightarrow \mathrm{R}_{2} \mathrm{TeCl}_{2}+\mathrm{HCl}
\end{array}
$$

$$
\mathrm{R}=\text { ( } p \text {-hydroxyphenyl/ } p \text {-methoxyphenyl/ bis(3-methyl-4-hydroxyphenyl) }
$$

Scheme 1 depicts the template condensation reactions of diaryltellurium(IV)dichlorides and 1, 2-diaminopropane in presence of $\mathrm{PtCl}_{2} / \mathrm{PdCl}_{2} / \mathrm{NiCl}_{2} \cdot 6 \mathrm{H}_{2} \mathrm{O}$, in the molar ratio 2:2:1 in dry methanol. The general composition for these complexes was found $\left[\mathrm{MLX}_{2}\right]$ for $\mathrm{Ni}(\mathrm{II})$; $[\mathrm{ML}] \mathrm{X}_{2}$ for $\mathrm{Pt}(\mathrm{II})$ and $\mathrm{Pd}(\mathrm{II})$ complexes (where $\mathrm{L}=10$-membered ditellurium tetraazamacrocyclic ligand and $\mathrm{X}=\mathrm{Cl}$ ). These complexes are coloured, crystalline solids and are soluble in DMSO and DMF.

\section{Infrared spectra}

The preliminary identification of the metal complexes has been obtained from infrared spectra (Table 2). A pair of bands were present in the spectrum of 1,2-diaminopropane corresponding to $\mathrm{v}\left(\mathrm{NH}_{2}\right)$, while no such bands were observed in case of the metal complexes. Instead, a new single sharp band appeared in all the metal complexes in the region 3163-3277 $\mathrm{cm}^{-1}$ (sometimes mixed with $v_{\mathrm{O}-\mathrm{H}}$ ) corresponding to stretching vibration of $\mathrm{N}-\mathrm{H}$ group ${ }^{31}$, which provide an evidence for the proposed skeleton of the macrocyclic moiety. The lower value of $v_{(\mathrm{N}-\mathrm{H})}$ may be explained on the basis of drift of electron density from the amine nitrogen towards the metal ion. This contention was further supported by the presence of medium to strong intensity band at $\sim 1610-1630 \mathrm{~cm}^{-1}$ and $812-827 \mathrm{~cm}^{-1}$ attributed to N-H deformations coupled with $\mathrm{N}-\mathrm{H}$ out of plane bending vibrations ${ }^{40}$.
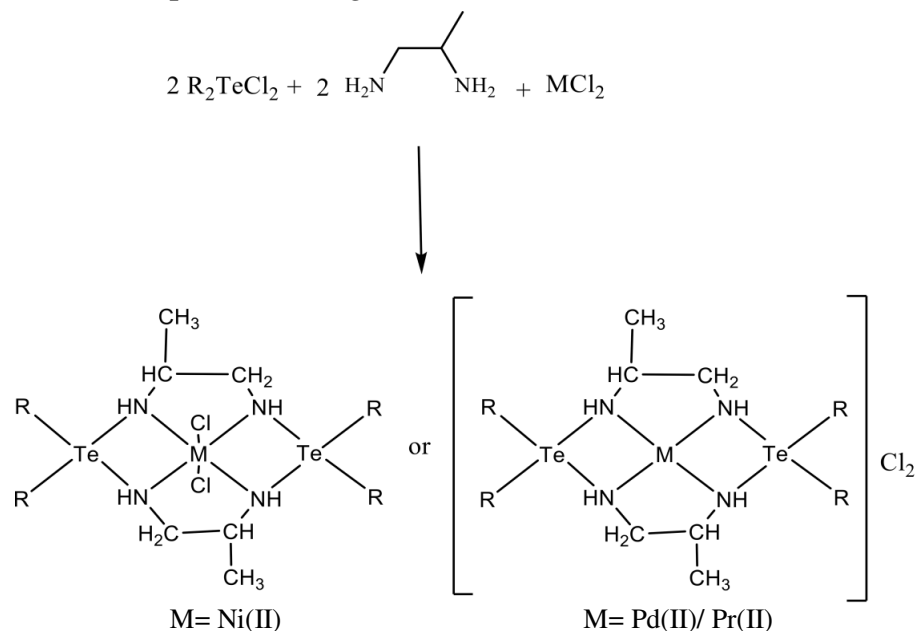

Where, $\mathrm{L}^{1} ; \mathrm{R}=p$-hydroxyphenyl, $\mathrm{L}^{2} ; \mathrm{R}=3$-methyl-4-hydroxyphenyl, $\mathrm{L}^{3} ; \mathrm{R}=p$-methoxyphenyl

Scheme 1. Formation of the $\mathrm{Ni}(\mathrm{II}), \mathrm{Pd}(\mathrm{II})$ and $\mathrm{Pt}(\mathrm{II})$ complexes 
Medium to weak intensity bands present in the region $\sim 1172 \mathrm{~cm}^{-1}$ may be assigned to $\mathrm{C}-\mathrm{N}$ stretching vibration ${ }^{41}$. The bands in the region $444-477 \mathrm{~cm}^{-1}$ assigned to $\mathrm{M}-\mathrm{N}$ stretching vibrations ${ }^{42,43}$ further support the formation of macrocyclic moiety coordinated through nitrogen atom. Presence of the new weak intensity absorption bands near $427-418 \mathrm{~cm}^{-1}$ corresponding to $\mathrm{Te}-\mathrm{N}$ vibration also supports the formation of tellurium containing macrocyclic ring ${ }^{30}$. Further medium to weak intensity bands in the far infrared region, 308$318 \mathrm{~cm}^{-1}$ may reasonably be assigned to $v(\mathrm{Ni}-\mathrm{Cl})$ vibration ${ }^{42-44}$.

\section{Proton NMR spectra}

In the ${ }^{1} \mathrm{H}$ NMR spectrum of 1,2-diaminopropane, $\mathrm{H}_{2} \mathrm{~N}-\mathrm{CH}\left(\mathrm{CH}_{3}\right)-\mathrm{CH}_{2}-\mathrm{NH}_{2}$, the signals appeared at $0.45(4 \mathrm{H}), 1.25(3 \mathrm{H}), 1.67(2 \mathrm{H})$ and1.67(2H) and $1.83(1 \mathrm{H}) \delta \mathrm{ppm}$ due to amino, methyl, methylene and methanetriyl/methine groups, respectively ${ }^{45,46}$. In the ${ }^{1} \mathrm{H}$ NMR spectra of all the metal complexes (Table 3), absence of signal due to primary amino group and appearance of a broad singlet at 1.99-2.30 $\delta$ ppm assignable to coordinated secondary amino group ${ }^{31}$ supports the formation of macrocyclic skeleton.

The signals of hydrogen atoms from the methyl protons of the propylenic chain and phenyl ring appeared as a singlet at $0.88-1.40$ and 2.52-2.62 $\delta$ ppm respectively. Coordination of ligand through the nitrogen atom of the amino group resulted in a downfield shift of signals (multiplet at $\sim 2.87$ to $3.37 \delta \mathrm{ppm}$ ) due to methylene and methanetriyl protons. The signals due to phenyl protons in the metal complexes appeared at slightly upfield side (6.82-7.84 $\delta \mathrm{ppm})$ in comparison to the parent diaryltellurium dichlorides ${ }^{35,36,47}$, as two chlorine atoms are replaced by two nitrogen atoms causing flow of electron density from nitrogen to tellurium. Further, independence of chemical shifts of aryl protons on the nature of metal ions, also confirms that tellurium atom is not coordinating with the metal ions.

Thus, proton NMR studies also support the formation of 10-membered ditellurium tetraazamacrocycles and their quadri dentate ligation behavior as predicted by infra-red spectroscopic studies.

\section{Electronic spectra and magnetic measurements}

\section{Nickel complexes}

The electronic spectra of the $\mathrm{Ni}(\mathrm{II})$ complexes recorded in $\mathrm{BaSO}_{4}$ exhibited three spin allowed bands in the range of 9842-10100, 14525-15243 and 23419-29740 $\mathrm{cm}^{-1}$ (Table 4) assignable to ${ }^{3} \mathrm{~A}_{2 \mathrm{~g}} \rightarrow{ }^{3} \mathrm{~T}_{2 \mathrm{~g}},{ }^{3} \mathrm{~T}_{1 \mathrm{~g}}(\mathrm{~F})$ and ${ }^{3} \mathrm{~T}_{1 \mathrm{~g}}(\mathrm{P})$ transitions respectively corresponding to an octahedral/distorted octahedral geometry ${ }^{48,49}$. Also, the ratio of $v_{2} / v_{1}$ was found to be $\approx 1.4$, indicating $^{50}$ an octahedral geometry for $\mathrm{Ni}(\mathrm{II})$ complexes. The third spin allowed d-d transitions appeared as a shoulder on the charge transfer bands and extended up to $22 \times 10^{3} \mathrm{~cm}^{-1}$, as reported ${ }^{51}$ for other $\mathrm{Ni}(\mathrm{II})$ complexes of tetraazamacrocycles. The magnetic moment of $\mathrm{Ni}$ (II) complexes lay in the range of 3.01-3.19 $\mu \mathrm{B}$, which also suggest an octahedral environment around nickel(II) ion and precludes the possibility of a square planar geometry $^{52}$.

\section{Palladium complexes}

$\mathrm{Pd}(\mathrm{II})$ complexes are diamagnetic as expected with spin paired $\mathrm{d}^{8}$ system. Electronic absorption spectra of the $\mathrm{Pd}(\mathrm{II})$ complexes recorded in $\mathrm{BaSO}_{4}$ displayed two bands in the region 20618-21100 and 26315-28571 $\mathrm{cm}^{-1}$, attributed to ${ }^{1} \mathrm{~A}_{1 \mathrm{~g}} \rightarrow{ }^{1} \mathrm{~A}_{2 \mathrm{~g}}$ and ${ }^{1} \mathrm{~A}_{1 \mathrm{~g}} \rightarrow{ }^{1} \mathrm{~B}_{1 \mathrm{~g}}$ respectively (Table 4). These transitions in the $\mathrm{Pd}(\mathrm{II})$ complexes are consistent with the square planar coordination around palladium ${ }^{48,53}$. 
Table 2. Important IR data $\left(\mathrm{cm}^{-1}\right)$ for metal complexes

\begin{tabular}{cccccccc}
\hline Complex & $v_{\mathrm{N}-\mathrm{H}}$ & $\begin{array}{c}\mathrm{N}-\mathrm{H} \\
\text { def. }\end{array}$ & $\begin{array}{c}\text { N-H out } \\
\text { of plane } \\
\text { bending }\end{array}$ & $v_{\mathrm{C}-\mathrm{N}}$ & $v_{\mathrm{M}-\mathrm{N}}$ & $v_{\mathrm{M}-\mathrm{Cl}}$ & $v_{\mathrm{Te}-\mathrm{N}}$ \\
\hline$\left[\mathrm{NiL}^{1} \mathrm{Cl}_{2}\right]$ & $3163 \mathrm{~m}$ & $1625 \mathrm{~s}$ & $823 \mathrm{~s}$ & $1171 \mathrm{~s}$ & $452 \mathrm{~m}$ & $310 \mathrm{~m}$ & $419 \mathrm{w}$ \\
{$\left[\mathrm{NiL}^{2} \mathrm{Cl}_{2}\right]$} & $*$ & $1615 \mathrm{~m}$ & $814 \mathrm{~m}$ & $1175 \mathrm{~m}$ & $444 \mathrm{~m}$ & $318 \mathrm{~m}$ & $426 \mathrm{w}$ \\
{$\left[\mathrm{NiL}^{3} \mathrm{Cl}_{2}\right]$} & $3189 \mathrm{~m}$ & $1612 \mathrm{~s}$ & $823 \mathrm{~m}$ & $1178 \mathrm{~m}$ & $449 \mathrm{~m}$ & $308 \mathrm{w}$ & $418 \mathrm{w}$ \\
{$\left[\mathrm{PdL}^{1}\right] \mathrm{Cl}_{2}$} & $3276 \mathrm{~m}$ & $1610 \mathrm{~m}$ & $826 \mathrm{~s}$ & $1173 \mathrm{~s}$ & $468 \mathrm{~m}$ & - & $422 \mathrm{w}$ \\
{$\left[\mathrm{PdL}^{2}\right] \mathrm{Cl}_{2}$} & $3277 \mathrm{~m}$ & $1612 \mathrm{~m}$ & $813 \mathrm{~m}$ & $1167 \mathrm{~m}$ & $477 \mathrm{~m}$ & - & $427 \mathrm{w}$ \\
{$\left[\mathrm{PdL}^{3}\right] \mathrm{Cl}_{2}$} & $3201 \mathrm{~m}$ & $1626 \mathrm{~m}$ & $816 \mathrm{~m}$ & $1161 \mathrm{~m}$ & $471 \mathrm{~m}$ & - & $418 \mathrm{w}$ \\
{$\left[\mathrm{PtL}^{1}\right] \mathrm{Cl}_{2}$} & $3180 * \mathrm{~m}$ & $1610 \mathrm{~m}$ & $825 \mathrm{~s}$ & $1174 \mathrm{~s}$ & $460 \mathrm{~m}$ & - & $419 \mathrm{w}$ \\
{$\left[\mathrm{PtL}^{2}\right] \mathrm{Cl}_{2}$} & $3250 * \mathrm{~m}$ & $1630 \mathrm{~m}$ & $812 \mathrm{~s}$ & $1150 \mathrm{~m}$ & $464 \mathrm{~m}$ & - & $420 \mathrm{w}$ \\
{$\left[\mathrm{PtL}^{3}\right] \mathrm{Cl}_{2}$} & $3166 \mathrm{~m}$ & $1625 \mathrm{~m}$ & $827 \mathrm{~m}$ & $1174 \mathrm{~m}$ & $446 \mathrm{w}$ & - & $418 \mathrm{w}$ \\
\hline
\end{tabular}

( $m=$ medium, $b=$ broad, $s=$ strong, $w=$ weak $) *$ mixed with $v_{O-H}$ band

Table 3. ${ }^{1} \mathrm{H}$ NMR spectral data $\left(\delta\right.$ ppm) for the metal complexes in DMSO- $d_{6}$

Complex Chemical shift, $\delta$ ppm

$\left[\mathrm{NiL}^{1} \mathrm{Cl}_{2}\right] 2.14$ (s, 4H, -NH-), 1.40 (d, 6H, aliphatic $\left.-\mathrm{CH}_{3}\right)$ 2.87-3.30 (m, 6H, - $\mathrm{CH}_{2-}$, $\mathrm{CH}-$, propylenic chain), $6.91^{\mathrm{d}}$ and $7.76^{\mathrm{d}}(16 \mathrm{H}$, phenyl), $9.6(\mathrm{~s}, 4 \mathrm{H}, \mathrm{OH})$ 2.07 (s, 4H, -NH-), $0.88\left(\mathrm{~d}, 6 \mathrm{H}\right.$, aliphatic $\left.-\mathrm{CH}_{3}\right) 3.1-3.37(\mathrm{~m}, 6 \mathrm{H},-$

$\left[\mathrm{NiL}^{2} \mathrm{Cl}_{2}\right] \mathrm{CH}_{2^{-}},-\mathrm{CH}-$, propylenic chain), 2.62* (s, $\left.12 \mathrm{H}, \mathrm{Ar}-\mathrm{CH}_{3}\right), 6.94^{\mathrm{d}}, 7.59^{\mathrm{d}}$ and $7.67^{\mathrm{s}}(12 \mathrm{H}$, phenyl) $9.54(\mathrm{~s}, 4 \mathrm{H}, \mathrm{OH})$

$2.12(\mathrm{~s}, 4 \mathrm{H},-\mathrm{NH}-), 1.24\left(\mathrm{~d}, 6 \mathrm{H}\right.$, aliphatic $\left.-\mathrm{CH}_{3}\right)$ 2.89-3.29 (m, 6H, -

$\left[\mathrm{NiL}^{3} \mathrm{Cl}_{2}\right] \mathrm{CH}_{2^{-}},-\mathrm{CH}-$, propylenic chain $), 3.35\left(\mathrm{~s}, 12 \mathrm{H},-\mathrm{OCH}_{3}\right), 6.82^{\mathrm{d}}$ and $7.84^{\mathrm{d}}$ $(16 \mathrm{H}$, phenyl)

$\left[\mathrm{PdL}^{1}\right]_{\mathrm{Cl}_{2}} 2.30(\mathrm{~s}, 4 \mathrm{H},-\mathrm{NH}-), 1.31\left(\mathrm{~d}, 6 \mathrm{H}\right.$, aliphatic $\left.-\mathrm{CH}_{3}\right)$ 2.88-3.37 (m, 6H, - $\mathrm{CH}_{2-}$, $\mathrm{CH}-$, propylenic chain), $6.92^{\mathrm{d}}$ and $7.71^{\mathrm{d}}(16 \mathrm{H}$, phenyl), $8.5(\mathrm{~s}, 4 \mathrm{H}, \mathrm{OH})$ $2.16(\mathrm{~s}, 4 \mathrm{H},-\mathrm{NH}-), 1.35\left(\mathrm{~d}, 6 \mathrm{H}\right.$, aliphatic $\left.-\mathrm{CH}_{3}\right) 3.01-3.32(\mathrm{~m}, 6 \mathrm{H}$, $\left[\mathrm{PdL}^{2}\right] \mathrm{Cl}_{2} \mathrm{CH}_{2^{-}},-\mathrm{CH}-$, propylenic chain $), 2.52^{*}\left(\mathrm{~s}, 12 \mathrm{H}, \mathrm{Ar}-\mathrm{CH}_{3}\right), 6.92^{\mathrm{d}}, 7.58^{\mathrm{d}}$ and $7.67^{\mathrm{s}}(12 \mathrm{H}$, phenyl), $8.51(\mathrm{~s}, 4 \mathrm{H}, \mathrm{OH})$

$\left[\mathrm{PtL}^{1}\right] \mathrm{Cl}_{2} 2.12(\mathrm{~s}, 4 \mathrm{H},-\mathrm{NH}-), 1.32\left(\mathrm{~d}, 6 \mathrm{H}\right.$, aliphatic $\left.-\mathrm{CH}_{3}\right) 3.03-3.24\left(\mathrm{~m}, 6 \mathrm{H},-\mathrm{CH}_{2}-\right.$, $\mathrm{CH}-$, propylenic chain), $6.91^{\mathrm{d}}$ and $7.66^{\mathrm{d}}(16 \mathrm{H}$, phenyl $), 8.89(\mathrm{~s}, 4 \mathrm{H}, \mathrm{OH})$ 1.99 (s, 4H, -NH-), 1.27 (d, 6H, aliphatic $\left.-\mathrm{CH}_{3}\right)$ 2.94-3.31 (m, 6H, $\left[\mathrm{PtL}^{2}\right] \mathrm{Cl}_{2} \mathrm{CH}_{2^{-}},-\mathrm{CH}-$, propylenic chain), $2.53\left(\mathrm{~s}, 12 \mathrm{H}, \mathrm{Ar}-\mathrm{CH}_{3}\right), 6.87^{\mathrm{d}}, 7.11^{\mathrm{d}} \&$ $7.41^{\mathrm{s}}(12 \mathrm{H}$, phenyl $), 8.8(\mathrm{~s}, 4 \mathrm{H}, \mathrm{OH})$

$(s=$ singlet, $d=$ doublet, $t=$ triplet, $m=$ multiplet, Ar = aromatic $) ; *$ may be mixed with solvent peak

\section{Platinum complexes}

The magnetic moment of $\mathrm{Pt}(\mathrm{II})$ complexes indicates that the complexes are diamagnetic in nature as expected. The electronic absorption spectra of these complexes displayed two bands in the region $21700-24878$ and $30218-32211 \mathrm{~cm}^{-1}$ corresponding to ${ }^{1} \mathrm{~A}_{1 \mathrm{~g}} \rightarrow{ }^{1} \mathrm{~B}_{1 \mathrm{~g}}$ and $\mathrm{CT}$ bands ${ }^{53-55}$ respectively (Table 4 ) which is consistent with the proposed stereochemistry of the $\mathrm{Pt}(\mathrm{II})$ complexes. Thus, all the complexes formed by $\mathrm{Pt}(\mathrm{II})$ metal with the macrocycles are square planar. 
Table 4. Electronic absorption spectra and magnetic moment data for the metal complexes

\begin{tabular}{cccc}
\hline Complex & $\begin{array}{c}\text { Band } \\
\text { Position, } \mathrm{cm}^{-1}\end{array}$ & Assignments & $\begin{array}{c}\text { Observed magnetic } \\
\text { moment, } \mu_{\mathrm{B}}\end{array}$ \\
\hline$\left[\mathrm{NiL}^{1} \mathrm{Cl}_{2}\right]$ & 9940 & ${ }^{3} \mathrm{~A}_{2 \mathrm{~g}} \rightarrow{ }^{3} \mathrm{~T}_{2 \mathrm{~g}}(\mathrm{~F})$ & \\
& 15243 & ${ }^{3} \mathrm{~A}_{2 \mathrm{~g}} \rightarrow{ }^{3} \mathrm{~T}_{1 \mathrm{~g}}(\mathrm{~F})$ & 3.14 \\
& 23419 & ${ }^{3} \mathrm{~A}_{2 \mathrm{~g}} \rightarrow{ }^{3} \mathrm{~T}_{1 \mathrm{~g}}(\mathrm{P})$ & \\
{$\left[\mathrm{NiL}^{2} \mathrm{Cl}_{2}\right]$} & 9842 & ${ }^{3} \mathrm{~A}_{2 \mathrm{~g}} \rightarrow{ }^{3} \mathrm{~T}_{2 \mathrm{~g}}(\mathrm{~F})$ & \\
& 29992 & ${ }^{3} \mathrm{~A}_{2 \mathrm{~g}} \rightarrow{ }^{3} \mathrm{~T}_{1 \mathrm{~g}}(\mathrm{~F})$ & 3.01 \\
& 10100 & ${ }^{3} \mathrm{~A}_{2 \mathrm{~g}} \rightarrow{ }^{3} \mathrm{~T}_{1 \mathrm{~g}}(\mathrm{P})$ & \\
{$\left[\mathrm{NiL}^{3} \mathrm{Cl}_{2}\right]$} & 14525 & ${ }^{3} \mathrm{~A}_{2 \mathrm{~g}} \rightarrow{ }^{3} \mathrm{~T}_{2 \mathrm{~g}}(\mathrm{~F})$ & \\
& 26550 & ${ }^{3} \mathrm{~A}_{2 \mathrm{~g}} \rightarrow{ }^{3} \mathrm{~T}_{1 \mathrm{~g}}(\mathrm{P})$ & 3.19 \\
{$\left[\mathrm{PdL}^{1}\right] \mathrm{Cl}_{2}$} & 20833 & ${ }^{1} \mathrm{~A}_{1 \mathrm{~g}} \rightarrow{ }^{1} \mathrm{~A}_{2 \mathrm{~g}}$ & \\
& 26315 & ${ }^{1} \mathrm{~A}_{1 \mathrm{~g}} \rightarrow{ }^{1} \mathrm{~B}_{1 \mathrm{~g}}$ & Diamagnetic \\
{$\left[\mathrm{PdL}^{2}\right] \mathrm{Cl}_{2}$} & 20618 & ${ }^{1} \mathrm{~A}_{1 \mathrm{~g}} \rightarrow{ }^{1} \mathrm{~A}_{2 \mathrm{~g}}$ & Diamagnetic \\
& 28571 & ${ }^{1} \mathrm{~A}_{1 \mathrm{~g}} \rightarrow{ }^{1} \mathrm{~B}_{1 \mathrm{~g}}$ & \\
{$\left[\mathrm{PdL}^{3}\right] \mathrm{Cl}_{2}$} & 21100 & ${ }^{1} \mathrm{~A}_{1 \mathrm{~g}} \rightarrow{ }^{1} \mathrm{~A}_{2 \mathrm{~g}}$ & Diamagnetic \\
& 27600 & ${ }^{1} \mathrm{~A}_{1 \mathrm{~g}} \rightarrow{ }^{1} \mathrm{~B}_{1 \mathrm{~g}}$ & \\
{$\left[\mathrm{PtL}^{1}\right] \mathrm{Cl}_{2}$} & 23580 & {$\left[{ }^{1} \mathrm{~A}_{1 \mathrm{~g}} \rightarrow{ }^{1} \mathrm{~B}_{1 \mathrm{~g}}\right]$} & Diamagnetic \\
& 32211 & ${ }_{\mathrm{CT}}$ & \\
{$\left[\mathrm{PtL}^{2}\right] \mathrm{Cl}_{2}$} & 21700 & ${ }^{1} \mathrm{~A}_{1 \mathrm{~g}} \rightarrow{ }^{1} \mathrm{~B}_{1 \mathrm{~g}}$ & Diamagnetic \\
& 31900 & ${ }_{\mathrm{CT}}$ & \\
{$\left[\mathrm{PtL}^{3}\right] \mathrm{Cl}_{2}$} & 24878 & ${ }^{1} \mathrm{~A}_{1 \mathrm{~g}} \rightarrow{ }^{1} \mathrm{~B}_{1 \mathrm{~g}}$ & Diamagnetic \\
\hline
\end{tabular}

\section{Antimicrobial results}

The minimum inhibitory concentration of the metal complexes against the selected fungal and bacterial strains was compared with the MIC of standard antibiotics cefadroxil and fluconazole in Table 5 and 6. Antibacterial and antifungal results show that all the synthesized metal complexes exhibit moderate to good activities as compared to their precursors (Figure $1 \& 2$ ).

Table 5. Minimum inhibitory concentration (MIC) values of the metal complexes against test bacteria

\begin{tabular}{cccccc}
\hline \multirow{2}{*}{ Complex } & \multicolumn{5}{c}{ MIC, $\mu \mathrm{g} \mathrm{mL} \mathrm{mL}^{-1}$} \\
\cline { 2 - 6 } & S. aureus & B. subtilis & E. coli & B. cereus & S. typhi \\
\hline $\mathrm{R}_{2} \mathrm{TeCl}_{2}(p$-Methooxyphenyl) & 25 & 25 & 25 & 25 & 25 \\
$\mathrm{R}_{2} \mathrm{TeCl}_{2}$ (p-Hydroxyphenyl) & 25 & 25 & 12.5 & 25 & 25 \\
$\mathrm{R}_{2} \mathrm{TeCl}_{2}(3-$ Methyl-4-hydroxyphenyl) & 12.5 & 25 & 25 & 25 & 25 \\
1,2-Diaminopropane & 25 & 25 & 25 & 12.5 & 25 \\
{$\left[\mathrm{NiL}^{1} \mathrm{Cl}_{2}\right]$} & 12.5 & 12.5 & 25 & 12.5 & 12.5 \\
{$\left[\mathrm{NiL}^{2} \mathrm{Cl}_{2}\right]$} & $\mathbf{6 . 2 5}$ & $\mathbf{6 . 2 5}$ & 12.5 & 12.5 & 25 \\
{$\left[\mathrm{NiL}^{3} \mathrm{Cl}_{2}\right]$} & 12.5 & 12.5 & 12.5 & 12.5 & 12.5 \\
{$\left[\mathrm{PdL}^{1}\right] \mathrm{Cl}_{2}$} & 12.5 & 12.5 & 12.5 & 25 & 25 \\
{$\left[\mathrm{PdL}^{2}\right] \mathrm{Cl}_{2}$} & 12.5 & 12.5 & 25 & 12.5 & 25 \\
{$\left[\mathrm{PdL}^{3}\right] \mathrm{Cl}_{2}$} & 12.5 & 12.5 & 12.5 & 12.5 & 12.5 \\
{$\left[\mathrm{PtL}^{1}\right] \mathrm{Cl}_{2}$} & $\mathbf{6 . 2 5}$ & $\mathbf{6 . 2 5}$ & $\mathbf{6 . 2 5}$ & $\mathbf{6 . 2 5}$ & 12.5 \\
{$\left[\mathrm{PtL}^{2}\right] \mathrm{Cl}_{2}$} & $\mathbf{6 . 2 5}$ & $\mathbf{6 . 2 5}$ & 12.5 & $\mathbf{6 . 2 5}$ & 12.5 \\
{$\left[\mathrm{PtL}^{3}\right] \mathrm{Cl}_{2}$} & $\mathbf{6 . 2 5}$ & $\mathbf{6 . 2 5}$ & $\mathbf{1 2 . 5}$ & $\mathbf{6 . 2 5}$ & $\mathbf{6 . 2 5}$ \\
$\mathrm{Cefadroxil}^{2}$ & $\mathbf{3 . 1 2}$ & $\mathbf{1 . 5 6}$ & $\mathbf{3 . 1 2}$ & $\mathbf{1 . 5 6}$ & $\mathbf{3 . 1 2}$ \\
\hline
\end{tabular}


Table 6. Minimum inhibitory concentration (MIC) values of the metal complexes against test fungi

\begin{tabular}{cccc}
\hline \multirow{2}{*}{ Complex } & \multicolumn{3}{c}{$\mathrm{MIC}, \mu \mathrm{g} \mathrm{mL}^{-1}$} \\
\cline { 2 - 4 } & A. niger & A. fumigatus & C. albicans \\
\hline $\mathrm{R}_{2} \mathrm{TeCl}_{2}$ (p-Methooxyphenyl) & 25 & 25 & 25 \\
$\mathrm{R}_{2} \mathrm{TeCl}_{2}$ (p-Hydroxyphenyl) & 25 & 25 & 25 \\
$\mathrm{R}_{2} \mathrm{TeCl}_{2}$ (3-Methyl-4-hydroxyphenyl) & 25 & 12.5 & 25 \\
1,2-Diaminopropane & 25 & 25 & 25 \\
{$\left[\mathrm{NiL}^{1} \mathrm{Cl}_{2}\right]$} & 12.5 & 25 & 12.5 \\
{$\left[\mathrm{NiL}^{2} \mathrm{Cl}_{2}\right]$} & 12.5 & 12.5 & 12.5 \\
{$\left[\mathrm{NiL}^{3} \mathrm{Cl}_{2}\right]$} & 12.5 & 12.5 & 12.5 \\
{$\left[\mathrm{PdL}^{1}\right] \mathrm{Cl}_{2}$} & 25 & 12.5 & 12.5 \\
{$\left[\mathrm{PdL}^{2}\right] \mathrm{Cl}_{2}$} & 12.5 & 12.5 & 12.5 \\
{$\left[\mathrm{PdL}^{3}\right] \mathrm{Cl}_{2}$} & 12.5 & 12.5 & 12.5 \\
{$\left[\mathrm{PtL}^{1}\right] \mathrm{Cl}_{2}$} & 12.5 & $\mathbf{6 . 2 5}$ & $\mathbf{6 . 2 5}$ \\
{$\left[\mathrm{PtL}^{2}\right] \mathrm{Cl}_{2}$} & $\mathbf{6 . 2 5}$ & $\mathbf{6 . 2 5}$ & $\mathbf{6 . 2 5}$ \\
{$\left[\mathrm{PtL}^{3}\right] \mathrm{Cl}_{2}$} & $\mathbf{1 2 . 5}$ & $\mathbf{6 . 2 5}$ & 12.5 \\
Fluconazole & $\mathbf{3 . 1 2}$ & $\mathbf{3 . 1 2}$ & $\mathbf{1 . 5 6}$ \\
\hline
\end{tabular}

However, Pt(II) complexes showed a MIC ranging from 3.12-12.5 $\mu \mathrm{g} / \mathrm{mL}$. Thecomplex, $\left[\mathrm{PtL}^{3}\right] \mathrm{Cl}_{2}$ also showed MIC of $3.12 \mu \mathrm{g} / \mathrm{mL}$ against the bacterial strain E. coli and S. typhi and fungal strain $A$. niger, which is equal to the minimum inhibitory concentration of standard antibiotics, cefadroxil and fluconazole respectively against the same bacterial and fungal strain. MIC of the complex, $\left[\mathrm{PtL}^{1}\right] \mathrm{Cl}_{2}$ was found to be $3.12 \mu \mathrm{g} / \mathrm{mL}$, which is equal to the MIC shown by the standard drug cefadroxil. The complex, $\left[\mathrm{PtL}^{2}\right] \mathrm{Cl}_{2}$ also exhibited good antifungal activity ( $\mathrm{MIC}=3.12 \mu \mathrm{g} / \mathrm{mL}$ ) against the fungal strain A. niger and A. fumigatus, which is equal to the standard antifungal drug fluconazole.

In general the antibacterial (Figure 1) and antifungal (Figure 2) activities of the metal complexes follow the order:

$$
\begin{aligned}
& \mathrm{Pt}(\mathrm{II})>\mathrm{Pd}(\mathrm{II})>\mathrm{Ni}(\mathrm{II}) \\
& \mathrm{Pt}(\mathrm{II})>\mathrm{Pd}(\mathrm{II}) \approx \mathrm{Ni}(\mathrm{II})
\end{aligned}
$$

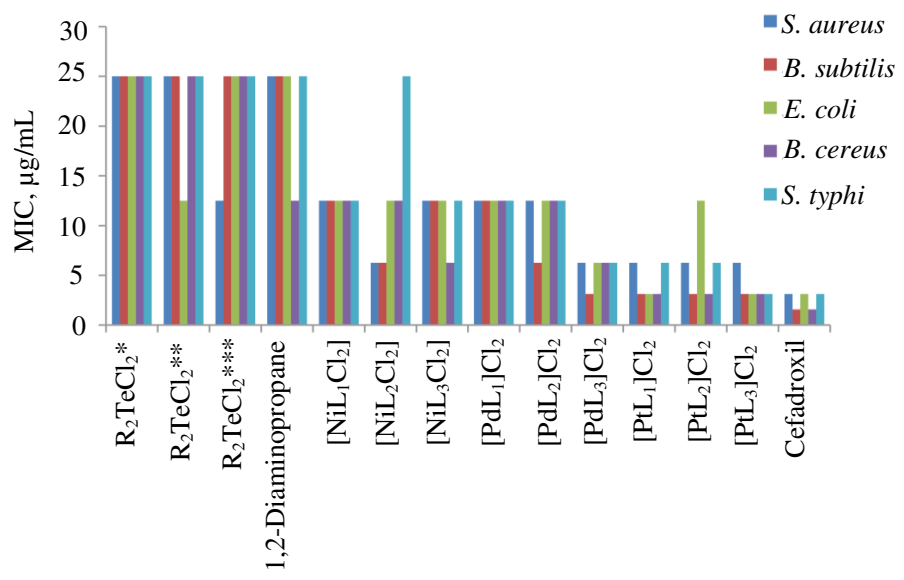

Figure 1. Antibacterial activity 


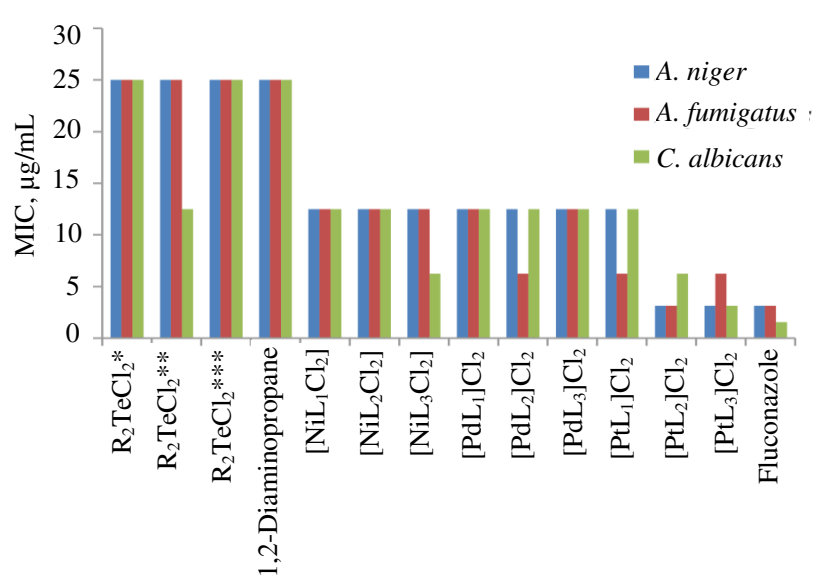

Figure 2. Antifungal activity

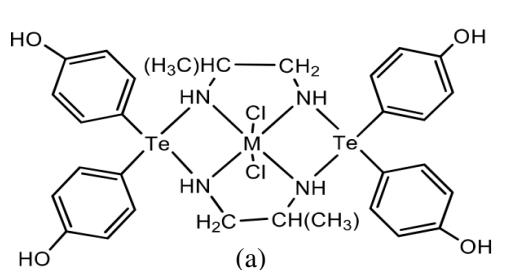

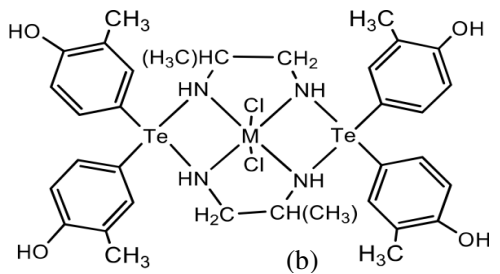

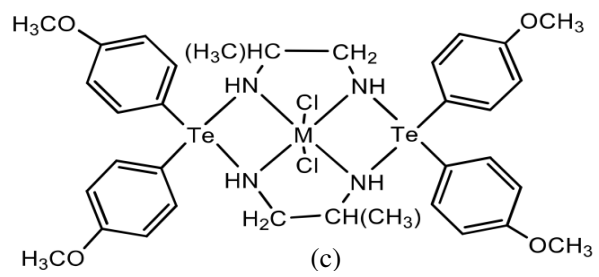

Figure 3. Proposed structure of the ditellurium tetraazamacrocyclic metal complexes of the type $\left[\mathrm{ML}^{1} \mathrm{Cl}_{2}\right]$ (a), $\left[\mathrm{ML}^{2} \mathrm{Cl}_{2}\right]$ (b) and $\left[\mathrm{ML}^{3} \mathrm{Cl}_{2}\right]$ (c), where $\mathrm{M}=\mathrm{Ni}(\mathrm{II}), \mathrm{Pd}(\mathrm{II})$ and $\mathrm{Pt}(\mathrm{II})$

\section{Conclusion}

We describe the synthesis and characterization of tellurium containing tetraazamacrocyclic metal complexes of $\mathrm{Ni}(\mathrm{II}), \mathrm{Pd}(\mathrm{II})$ and $\mathrm{Pt}(\mathrm{II})$. On the basis of IR, ${ }^{1} \mathrm{H}$ NMR, magnetic moment and electronic spectral studies we assumed $\mathrm{Pd}(\mathrm{II})$ and $\mathrm{Pt}(\mathrm{II})$ complexes with square planar coordination geometry while $\mathrm{Ni}$ (II) complexes with distorted octahedral geometry. The proposed structures for the $\mathrm{Ni}$ (II) complexes are shown in Figure 3 (in case of $\mathrm{Pt}(\mathrm{II})$ and $\mathrm{Pd}(\mathrm{II})$ complexes the $\mathrm{Cl}$ atom will be outside the coordination sphere). In vitro antifungal and antibacterial screening of the complexes indicate that the platinum(II) complexes are highly active while the other metal complexes show moderate activity as compared to their precursors.

\section{Acknowledgement}

The authors are thankful to M. D. University, Rohtak for providing financial assistance and laboratory facilities. We also thank SAIF, P. U. Chandigarh for recording the spectral and CHN analyses data. 


\section{References}

1. Chandra S, Tyagi M and Agrawal S, J Serb Chem Soc., 2010, 75(7), 935-941; DOI:10.2298/JSC090804069C

2. Tyagi M, Chandra S and Choudhary S K, J Chem Pharma Res., 2011, 3(1), 56-63.

3. Nirmala G, Kalilur Rahiman A, Sreedaran S, Jegadeesh R, Raaman N and Narayanan V, J Mol Struct., 2011, 989(1-3), 91-100; DOI:10.1016/j.molstruc.2011.01.010

4. Niasari M S, Bazarganipour M, Ganjali M R and Norouzi P, Transition Met Chem., 2007, 32(1), 9-15; DOI:10.1007/s11243-006-0109-y

5. Niasari M S and Davar F, Inorg Chem Commun., 2006, 9(2), 175-179; DOI:10.1016/j.inoche.2005.10.028

6. GaoZ, Tian G, Zhao G and Si C, Inorg Chem Commun., 2010, 13(4), 461-463; DOI:10.1016/j.inoche.2009.12.026

7. Demirbilek M and Pişkin E, J Biol Chem., 2008, 36(4), 263-271.

8. Matsubara T and Hirao K, J Mol Str (Theochem.), 2002, 581(1-3), 203-213; DOI:10.1016/S0166-1280(01)00759-X

9. Sengupta P, Dinda R, Ghosh S and Sheldrick W S, Polyhedron, 2003, 22(3), 447453; DOI:10.1016/S0277-5387(02)01363-3

10. Singh D P, Kumar R and Singh J, J Enzy Inhib Med Chem., 2009, 24(3), 883-889; DOI:10.1080/14756360802456397

11. Bansal N and Dave S, Main Group Met Chem., 2013, 36, 101-107.

12. Chandra S, Gupta R, Gupta N and Bawa S S, Transition Met Chem., 2006, 31(2), 147-151; DOI:10.1007/s11243-005-6194-5

13. Girgis A S, Euro J Med Chem., 2008, 43(10), 2116-2121;

DOI:10.1016/j.ejmech.2007.12.010

14. Bhasin C P, Goswami K V and Gongiwala M, J Indian Coun Chem., 2009, 26(1), 12-22.

15. EI-Wahab Z H A, J Coord Chem., 2009, 43, 231.

16. Chaudhary A, Bansal N, Garjraj A and Singh R V, J Inorg Biochem., 2003, 96(2-3), 393-400; DOI:10.1016/S0162-0134(03)00157-0

17. Sharma R C, Vats R, Singh S and Agarwal S, J Inst Chem., 2007, 74, 119.

18. Ott I and Gust R, Anti-Cancer Agents Med Chem., 2007, 7(1), 95-110; DOI:10.2174/187152007779314071

19. Chandra S, Raizada S and Rani S, Spectrochim Acta A, 2008, 71(2), 720-724; DOI:10.1016/j.saa.2007.12.051

20. Lakomska I, Inorg Chim Acta, 2009, 362(3), 669-681; DOI:10.1016/j.ica.2008.02.030

21. Dwyer P O, Stevenson J and Johnson S, In: B. Lippert (Ed.), Cisplatin: Chemistry and Biochemistry of a leading anticancer Drug; Verlag Helvetica Chemica Acta: Zurich, 1999.

22. Dong W, Yang R and Yan L, Indian J Chem., 2001, 40A, 202-206.

23. Reddy P M, Prasad A V S S and Vadde R, Trans Met Chem., 2007, 32(4), 507-513; DOI:10.1007/s11243-007-0205-7

24. Salavati-Niasari M, J Mol Cat A, 2007, 272(1-2), 207-212;

DOI:10.1016/j.molcata.2007.03.053

25. Seto J, Tamura S, Asai N, Kishii N, Kijima Y and Matsuzawa N, Pure Appl Chem., 1996, 68(7), 1429-1434; DOI:10.1351/pac19966807142

26. Jones P G, Carman M and Arellano R D, J Chem Soc Dalton Trans., 1996, 2713 2717; DOI:10.1039/DT9960002713

27. Kienitz C O, Thone C and Jones P G, Inorg Chem., 1996, 35(13), 3990-3997; DOI:10.1021/ic951454d 
28. Mays M D, McCellough R D, Bailey A B, Cowan D O, Briden W A, Pochler T O and Kistenmecher T J, Synth Met., 1988, 27(3-4), 493-496; DOI:10.1016/03796779(88)90190-7

29. Higa K T and Harris D C, Organometallics, 1989, 8, 1674-1678; DOI:10.1021/om00109a016

30. Srivastava S and Kalam A, J Indian Chem Soc., 2006, 83, 563-567.

31. Rathee N and Verma K K, J Serb Chem Soc., 2012, 77(3), 325-333; DOI: $10.2298 / \mathrm{JSC} 101211200 \mathrm{R}$

32. Panda A, Coord Chem Rev., 2009, 253(-13-14), 1947-1965; DOI:10.1016/j.ccr.2009.03.025

33. Vogel A I, A Text Book of Quantitative Inorganic AnalysisIncluding Elementary Instrumental Analysis, $3{ }^{\text {rd }}$ Ed.; Longman: London, 1975, (a) p. 266, (b) p. 324, (c) p. 510 and (d) p. 511

34. Vogel A I, Test Book of Practical Organic Chemistry, $5^{\text {th }}$ Ed.; Longman: London, 1996.

35. Khandelwal B L, Kumar K and Berry F J, Inorg Chim Acta, 1981, 47, 135-137; DOI:10.1016/S0020-1693(00)89319-6

36. Khandelwal B L, Kumar K and Raina K, Synth React Inorg Met Org Chem., 1981, 11(1), 65-78; DOI:10.1080/00945718108059276

37. Petragnani $\mathrm{N}$ and Stefani $\mathrm{H}$ A, Tellurium in Organic Chemistry, $2^{\text {nd }}$ Ed.; Academic Press: London, 2007, 67, 2007, 76.

38. Cappuccino J C and Sherman N, Microbiology- A Laboratory Manual; Addison, Wesley: California, 1999, 263.

39. Pharmacopoeia of India, Volume 1, Controller of Publications: Ministry of Health Department, Government of India, New Delhi, 2007, 1, 37.

40. Rana V B, Singh P, Singh D P and Teotia M P, Polyhedron, 1982, 1, 377-381; DOI:10.1016/S0277-5387(00)80823-2

41. Panda A K, Panda A,Sutar S, Mishra P, Pradhan S, Ghos S and Pany S, J Indian Chem Soc., 2009, 86, 908.

42. Singh D, Kumar K, Kumar R and Singh J, J Serb Chem Soc., 2010, 75(2), 217-228; DOI:10.2298/JSC1002217S

43. Tyagi $\mathrm{M}$ and Chandra S, J Saudi Chem Soc., 2014, 18(1), 53-58; DOI:10.1016/j.jscs.2011.05.013

44. Nasman O S M, Phosphorous Sulfur Silicon Rel Ele., 2008, 183(7), 1541-1551; DOI:10.1080/10426500701690939

45. Silverstein R M, Spectrometric Identification of Organic Compounds, $4^{\text {th }}$ Ed.; John Wiley: New York, 1981.

46. Pavia D L, Lampman G M, Kriz G S and Vyvyan J R, Spectroscopy; Brooks/Cole, Cengage Learning India Pvt. Ltd.: New Delhi, 2007.

47. Raina K and Khandelwal B L, Indian J Chem., 1976, 14A, 63.

48. Lever A B P, Inorganic Electronic Spectroscopy; Elsevier: Amsterdam, 1968.

49. Dunn T M, in Modern Coordination Chemistry; Lewis J, Wilkins R G, Eds. Interscience: New York, 1960, 230.

50. Abe K, Matsufuji K, Ohba M and Okawa H, Inorg Chem., 2002, 41(17), 4461-4467; DOI:10.1021/ic020002f

51. Chandra S, Gupta K and Sharma S, Synth React Inorg Met Org Chem., 2001, 31(7), 1205-1215; DOI:10.1081/SIM-100106858

52. Dianu M L, Kriza A, Stanica N and Musuc A M, J Serb Chem Soc., 2010, 75(11), 1515-1531; DOI:10.2298/JSC091113121D 
53. Chandra S, Verma S and Meera P, J Indian Chem Soc., 2008, 85(9), 896-900.

54. Singh A and Singh P, Indian J Chem., 2000, 39A, 874-876.

55. Lal R S, Kumar A and Chakaraborty J, Indian J Chem., 2001, 40A, 422. 